\title{
Correction to: Eculizumab improves fatigue in refractory generalized myasthenia gravis
}

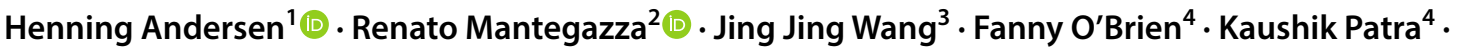 \\ James F. Howard Jr. ${ }^{\circ}$. . The REGAIN Study Group
}

Published online: 21 May 2019

(c) The Author(s) 2019

\section{Correction to: Quality of Life Research https://doi.org/10.1007/s11136-019-02148-2}

The article "Eculizumab improves fatigue in refractory generalized myasthenia gravis", written by "Henning Andersen, Renato Mantegazza, Jing Jing Wang, Fanny O’Brien, Kaushik Patra, James F. Howard Jr. and The REGAIN Study Group" was originally published electronically on the publisher's internet portal (currently SpringerLink) on 23 March 2019 without open access.

With the author(s)' decision to opt for Open Choice the copyright of the article changed on 20 May 2019 to (C) The Author(s) 2019 and the article is forthwith distributed under the terms of the Creative Commons Attribution 4.0 International License (http://creativecommons.org/licenses/ by/4.0/), which permits use, duplication, adaptation, distribution and reproduction in any medium or format, as long as you give appropriate credit to the original author(s) and the source, provide a link to the Creative Commons license and indicate if changes were made.

The original article has been corrected.

Open Access This article is distributed under the terms of the Creative Commons Attribution 4.0 International License (http://creativeco mmons.org/licenses/by/4.0/), which permits unrestricted use, distribution, and reproduction in any medium, provided you give appropriate credit to the original author(s) and the source, provide a link to the Creative Commons license, and indicate if changes were made.

The original article can be found online at https://doi.org/10.1007/ s11136-019-02148-2.

Henning Andersen

hennande@rm.dk

1 Department of Neurology, Aarhus University Hospital, Indgang J, Plan 5, Krydspunkt 504, Palle Juul-Jensens Boulevard, 8200 Aarhus N, Denmark

2 Foundation of the Carlo Besta Neurological Institute, IRCCS, Milan, Italy

3 Formerly of Alexion Pharmaceuticals, Inc., New Haven, CT, USA

4 Alexion Pharmaceuticals, Inc., New Haven, CT, USA

5 Department of Neurology, UNC School of Medicine, University of North Carolina at Chapel Hill, Chapel Hill, NC, USA 